\title{
MPRA
}

Munich Personal RePEc Archive

\begin{abstract}
Achieving an adequate balance between the level of complexity, objectivity and comparability which is required within the capital framework: credit ratings and the Standardized Approach (SA-CCR) for measuring Exposure at Default (EAD) for Counter-Party Credit Risk

Ojo, Marianne
\end{abstract}

North-West University South Africa

25 May 2014

Online at https://mpra.ub.uni-muenchen.de/56209/

MPRA Paper No. 56209, posted 28 May 2014 12:57 UTC 
ABSTRACT

\section{Achieving an Adequate Balance between the Level of Complexity, Objectivity and Comparability Which is Required within the Capital Framework: Credit Ratings and the Standardized Approach (SA-CCR) for Measuring Exposure at Default (EAD) for Counter-Party Credit Risk}

Credit ratings have assumed an increasingly formidable and important role over the years. An increased role and revisions to its foundations, have been triggered, not only in view of the shortcomings of credit ratings based criteria, as revealed through the recent Financial Crisis, but also the need to update Basel II - which has served as the foundation for credit ratings in several jurisdictions. Credit ratings serve various vital purposes, most notably of which include the determination of capital requirements, the identification and classification of assets, and the provision of reliable estimation and assessment of credit risk.

The criteria required to be satisfied by credit rating agencies, namely: objectivity, independence, transparency, disclosure, resources and credibility, are closely linked, since the level of comparability and consistency of information provided by such agencies, could also serve as a useful indicator that such information is reliable and credible.

In response to the changing financial environment - the evolution and emergence of new and more complex forms of risks and financial products, credit rating agencies have extended their scope beyond the coverage of their traditional products. As well as assessing whether the scope of products presently covered by rating agencies could be deemed adequately relevant to the criteria required to satisfy information being provided as credible, this paper also addresses the reliability of credit scoring methods and models. Are those measures used in estimating the probability of default, namely, financial statements, market prices of a firm's debt and equity, and appraisals of the firm's prospects and risk sufficiently indicative as to provide a reliable estimate of the firm's probability of default? 
The vital role of audits in verifying the credibility of information in financial statements is therefore evident. The reliability and consistency of credit ratings across different jurisdictions, sectors financial, non financial sectors, and rating agencies, as well as the reliability of the approach for assessing ratings constitute major areas to be addressed. This in part, being attributed to the difficulties with achieving a balance between risk-sensitivity and comparability.

The Basel III leverage ratios also being crucial to achieving an acceptable balance with risk-sensitivity - such that the capital framework is not considered unduly risk-sensitive - as was the case with Basel II.

The increased importance attributed to credit ratings is also reflected by the Basel Committee's recent introduction of the Standardized Approach (SA-CCR) for measuring exposure at default (EAD) for counter-party credit risk (CCR). The SA-CCR is intended to replace both current non-internal models approaches, the Current Exposure Method (CEM) and the Standardised Method (SM). The SA-CCR will apply to OTC derivatives, exchange-traded derivatives and long settlement transactions. Risk models have certainly become increasingly complex and relevant - however, is such level of complexity correspondingly and adequately balanced with the level of objectivity and comparability which is required within the capital framework?

Key Words: credit ratings, OTC derivatives, objectivity, forecasting, assets, liquidity, risk sensitivity, leverage ratios, audits, information asymmetries 


\title{
Achieving an Adequate Balance between the Level of Complexity, Objectivity and Comparability Which is Required within the Capital Framework: Credit Ratings and the Standardized Approach (SA-CCR) for Measuring Exposure at Default (EAD) for Counter-Party Credit Risk
}

\author{
Marianne Ojo ${ }^{1}$
}

\section{Introduction}

The criteria required to be satisfied by credit rating agencies, as a means of generating high quality external credit assessments, namely: ${ }^{2}$ objectivity, independence, transparency, disclosure, resources and credibility, are closely linked, since the level of comparability of information provided by such agencies, could also serve as a useful indicator that such information is reliable and credible. However these criteria - and particularly that relating to objectivity, have been called into question recently.

This has been triggered by the changing financial environment - as well as the evolution and emergence of new and more complex forms of risks and financial products. Correspondingly, credit rating agencies have responded by extending their scope beyond the coverage of their traditional products.

The uses of credit ratings, according to the Joint Forum, include the following: ${ }^{3}$

- the determination of capital requirements;

- the identificatio or classification of assets;

1 Professor, Faculty of Commerce and Administration, North-West University, South Africa Email:marianneojo@hotmail.com

2 As stipulated under Paragraph 91 of the Basel II framework. See Basel Committee on Banking Supervision, the Joint Forum, Stocktaking on the Use of Credit Ratings at page 20 http://www.bis.org/press/p090615.htm

3 Basel Committee on Banking Supervision, the Joint Forum, Stocktaking on the Use of Credit Ratings pages 3 and 4 
- the provision of credible valuation of credit risk;

- the determination of disclosure requirements; and

- the determination of prospectus eligibility

Revisions and Adjustments Undertaken By the Basel Committee to Improve the Effectiveness of Measures of Bank's Resilience to Financial Crises

Out of the five indicators of a bank's strength, as reflected by the CAMEL ${ }^{4}$ system, efforts made in relation to capital adequacy requirements will constitute the focus of this paper. Hence the ensuing section, section II, commences with an introduction to the Standardised Approach for Measuring Counter Party Credit Risk - as well as developments which have culminated in its introduction namely the gaps identified with Basel II, and the need to sufficiently account for previously unquantified volatile transactions and risks. The quality of information provided by credit ratings, as well as the role of credit ratings agencies in addressing asymmetric information will constitute one of those issues to be addressed under section III. In view of the ever increasing significance of risks in financial and regulatory environments, as well as the need to quantify and regulate such risks, should the quality of audits and the role assumed by audits not be factored into credit ratings processes? The role of audits in the capital markets of several major economies and their significance in verifying and facilitating credible, reliable and accurate information and signals within capital markets have been discussed extensively in the literature. Section IV highlights why audits and auditors have assumed such a vital role within an increasingly risk based regulatory environment. Section V then concludes by focussing on one of the themes of the paper - namely the need to balance the level of complexity, objectivity and comparability which is required within the capital framework. In view of considerable regulatory, audit and accounting differences which persist across jurisdictions, could credit ratings based criteria really be considered to be adequately objective? Furthermore, given the crucial role assumed by external auditors in the regulatory and supervisory process, as well as their prominence within the Basel Committee's Core Principles for Effective Banking Supervision, should this fundamental issue not constitute a greater focus for redress in emerging economies? Will recent efforts by the Committee to address capital adequacy and leverage ratios be undermined since an underlying

4 Capital Adequacy, Asset Quality, Management, Earnings and Liquidity 
issue has still not been addressed in several emerging economies? Are those emerging economies which are concerned justified in their reluctance to adequately embrace audits - based on cost- benefit considerations? These are amongst some of the points which this paper will seek to address. In so doing, the paper will contribute to the extant literature on the topic, not only through the recommendation of a novel approach and an alternative means whereby more reliable and credible information could be obtained, but also the rationale for adopting such means of verification. Furthermore, it will aim to demonstrate that information obtained from credit rating agencies, even if timely, could still fall short of the all-important attributes of reliability and credibility where sources of information have not been adequately verified as credible, and where transparency and disclosure measures do not exist to facilitate comparability within the process.

\section{The Standardised Approach for Measuring Counter Party Credit Risk (SA-CCR)}

The Standardised Approach for Measuring Counter Party Credit Risk (SA-CCR) replaces both current non-internal model approaches - the Current Exposure Method (CEM) and the Standardised Method (SM). Efforts aimed at ensuring that volatile transactions are captured - as well as previously unaccounted for risks, are evidenced by the following rationales for introducing the SA-CCR and the criticisms attributed to the previously existing non- internal model approaches - which include the fact: ${ }^{5}$

- That the Current Exposure Method, did not, in particular, distinguish between margined and unmargined transactions;

- That the supervisory add-on factor did not sufficiently capture the level of volatilities as observed over recent stress periods, and the recognition of netting was too simplistic and not reflective of economically meaningful relationships between derivatives positions;

- That the Standardised Method, even though more risk-sensitive than the Current Exposure

5 Basel Committee for Banking Supervision, Standardised Approach for Measuring Counter Party Credit Risk at page 1 http://www.bis.org/publ/bcbs279.htm 
Method, did not differentiate between margined and unmargined transactions or sufficiently capture the level of volatilities observed over stress periods in the last five years. Further, given the inability to implement the Standardised Method, or implementing it inconsistently.

- The relationship between current exposure and potential future exposure (PFE) was misrepresented in the Standardised Method because only current exposure or PFE was capitalised.

- Finally, the Standardised Method did not provide banks with a true non-internal model alternative for calculating EAD because the Standardised Method used internal methods for computing delta-equivalents for non-linear transactions.

The Second Consultative Paper, issued by the Basel Committee in January 2001, introduced the two Internal Ratings Based (IRB) methodologies - the Foundational IRB and the Advanced IRB methodologies. The Internal Ratings Based approach to capital requirements for credit risk, not only relies significantly on the internal assessment carried out by a bank, in relation to counterparties and exposures, but is also geared towards the achievement of two primary goals, namely: ${ }^{6}$,additional risk sensitivity“ and ,incentive compatibility“.

Basel II is premised on a three level approach which permits banks to select from three models, namely: the basic standardized model, the IRB foundation approach and the advanced ratings approach. According to the Consultative Document on Standard Approach to Credit Risk, ${ }^{7}$ capital requirements under the standardized approach are considered to be more syncronised and in harmony with the principal elements of banking risk - owing to the introduction of more differentiated risk weights and a broader recognition of techniques which are applied in mitigating risk whilst such techniques attempt to avoid undue complexity. As a result, capital ratios generated through the standardized approach, should adapt more to present and actual risks encountered by banks, than was the case previously.

Under Pillar One minimum capital requirements, operational risk is to be corroborated by capital.

6 In establishing an Internal Ratings Based approach, the Commitee's intention was directed at „fine tuning capital requirements with a greater degree of accuracy to the level of a bank's exposure to credit risks." Basel Committee on Banking Supervision, 'The Internal Ratings Based Approach' Supporting Document to the New Basel Capital Accord 2001 at pages 1 and $3 \mathrm{http}: / /$ www.bis.org/publ/bcbsca05.pdf

7 Basel Committee on Banking Supervision, Consultative Document, Standard Approach to Credit Risk, Supporting Document to the New Basel Accord January 2001 at page 1 http;//www.bis.org/publ/bcbsca04.pdf 
Measurement approaches for operational risk can be found in the Capital Requirements Directive (CRD) and there are three broad approaches to the capital assessment of operational risk which are as follows:

- Basic Indicator Approaches

- Standardized Approaches

- Internal Measurement Approach

Basel II constitutes the foundation for credit ratings in several jurisdictions. However, failures and flaws of Basel II, as revealed during the recent Financial Crisis have prompted revisions, which have been made to the framework for determining capital requirements for bank exposures to central counterparties - as introduced through a new section (Section XI) of Annex 4 of the International Convergence of Capital Measurement and Capital Standards: A Revised Framework - Comprehensive Version, June 2006 (hereinafter referred to as "Basel II"). ${ }^{8}$

Exposures to central counterparties arising from OTC derivatives, exchange-traded derivatives transactions, SFTs and long settlement transactions are to be subject to the counterparty credit risk treatment laid out in paragraphs 188 to 211 of the Annex (Section XI) of Annex 4 ). ${ }^{9}$ Exposures arising from the settlement of cash transactions (equities, fixed income, spot FX and spot commodities) are not subject to this treatment. ${ }^{10}$

Within the Basel II framework, external ratings are used for the purpose of enhancing the risk sensitivity of the framework. ${ }^{11}$ They are not only primarily used under the standardised approach for

8 „Regardless of whether a CCP is classified as a QCCP, a bank retains the responsibility to ensure that it maintains adequate capital for its exposures. Under Pillar 2 of Basel II, a bank should consider whether it might need to hold capital in excess of the minimum capital requirements if, for example, (i) its dealings with a CCP give rise to more risky exposures or (ii) where, given the context of that bank's dealings, it is unclear that the CCP meets the definition of a QCCP.“ See Basel Committee for Banking Supervision, Capital Requirements for Bank Exposures to Central Counterparties, April 2014 at page 4 http://www.bis.org/publ/bcbs282.htm

9 Basel Committee for Banking Supervision, Capital Requirements for Bank Exposures to Central Counterparties, April 2014 at page $6 \mathrm{http} / / / \mathrm{www}$. bis.org/publ/bcbs282.htm

10 ibid

11 „For example, by being incorporated into assessments of the credit quality of an exposure or creditworthiness of a counterparty - and thus the imposition of capital requirements." See Basel Committee for Banking Supervision, The Joint Forum, Stocktaking on the Use of Credit Ratings page 4 http://www.bis.org/press/p090615.htm 
credit risk, but also apply to risk-weight securitisations exposures - the different uses of external ratings corresponding to probability of default treatments under the standardised approaches, and to situations where the use of internally generated ratings is impossible or difficult given, for instance, the lack of statistical data for securitised products. ${ }^{12}$

According to the Basel Committee on Banking Supervision, the traditional rating agency product is ,,an assessment of the credit quality of individual debt issues of a firm. “13 In recognition of the changing financial environment, as well as more complex risks associated with financial products, in recent years, rating agencies have expanded their coverage to other debt products and have introduced variants or refinements of their traditional products. Despite efforts made by rating agencies to adapt to changes in the financial environment, their credit scoring methods, approaches and models, and the reliability of these - particularly measures based on market prices, may still be questioned. As is the case with the inability of capital adequacy ratios and measures, on their own, to provide adequately reliable indication of a bank's strength, robustness and resilience - particularly during periods of financial downturns, information provided by credit rating agencies should not be relied upon as being sufficient in their entirety. Just as liquidity and leverage ratios had to be introduced through Basel III to complement the risk-based capital adequacy framework for the inadequacies and flaws revealed during the recent Financial Crisis, there is need for closer collaboration between supervisory agencies, financial institutions, credit rating agencies as well as external auditors in order to maximise the benefits of those synergies arising from such a collaboration.

12 ibid

13 See Basel Committee on Banking Supervision Working Papers, No 3 August 2000, Credit Ratings and Complementary Sources of Credit Quality Information at page 5. „Four products of rating agencies that might possibly serve as complements to more traditional ratings in a regulatory regime that relied on external credit ratings. First, issuer ratings make it possible to expand the universe of firms with credit ratings beyond those that have issued public debt. Second, bank loan ratings adjust for differences in expected recoveries often observed for bank loans in default relative to bonds in default. Third, bank financial strength ratings, by measuring stand-alone credit quality, allow an assessment of the dependence on the safety net for any particular set of banks. Finally, sovereign ceilings, which reflect country risk, denote the maximum foreign-currency rating that an entity domiciled in a particular nation can receive, with very few exceptions." see ibid 


\section{Is Information Provided through Credit Ratings Agencies Superior to those of Macro}

Economic Indicators? This appears to be a jurisdictional based question.

„The recent crisis highlighted the interface between, and the complementary nature of, the macroprudential and microprudential elements of effective supervision. In their application of a risk-based supervisory approach, supervisors and other authorities need to assess risk in a broader context than that of the balance sheet of individual banks." 14

A distinction of the two categories assumed by credit ratings is required in order to facilitate the understanding of their role in impacting financial markets.

Credit ratings can be classified into two:

Investment grade designation

Speculative grade designation

The investment grade designation, the preferable and more elite class, is naturally the goal of many nations - and this also relates to benefits associated with being upgraded to this class - namely, lower financing costs.

Various empirical studies associated with the impact of being elevated or downgraded to either of these grades, have concluded on the basis that investment grade classes are often associated with lower spreads. According to a study undertaken by Jaramillo and Tejada, the investment grade designation reduces spreads significantly - ,by 36 percent above and beyond what is implied by macroeconomic fundamentals." ${ }^{\text {15 }}$ Further, as indicated in their investigation, empirical studies have, on the whole, discovered that better ratings are associated with lower spreads. ${ }^{16}$

14 Basel Committee for Banking Supervision, Core Principles for Effective Banking Supervision September 2012 at page 5

15 See IMF Working Paper, Sovereign Credit Ratings and Spreads in Emerging Markets: Does Investment Grade Matter? March 2011 WP/11/44 http://www.imf.org/external/pubs/cat/longres.cfm?sk=24677.0

16 „Cantor and Packer (1996) concluded that a one-notch deterioration in credit ratings raises spreads by $25 \%$. Kaminsky and Schmukler (2002) revealed that changes in sovereign debt ratings and outlooks affect financial markets in emerging economies, with average yield spreads increasing $2 \%$ points in response to a one-notch downgrade." See ibid at page 4

For further empirical studies on these see ibid 
Three basic types of information which are usually employed as a means of determining an enterprise' probability of default are: ${ }^{17}$ financial statements, market prices of a firm's debt and equity, and subjective appraisals of the firm's prospects and risk.

Audits constitute vital signalling mechanisms in capital markets - thus serving as crucial indicators to financial investors of the worth of the enterprise or firm which is being invested in or which may be potentially invested in. In view of the fundamental informational role assumed by audits in many industrial nations, it could be easily deduced that credit rating agencies would play less fundamental informational roles in these nations than in emerging economies. However such a role, given the significance of audits in such countries, is to be based on the level of reliability and credibility of information that could be provided by such agencies - and not on the impact of downgrading or upgrading credit ratings. The severe consequences of downgrading any country's credit ratings regardless of whether such a nation is an emerging economy or an industrial nation cannot be overemphasized. From such a perspective, the impact of downgrading or upgrading a nation's credit ratings is distinguished from credit agencies' roles or significance in providing reliable, credible and timely information.

Two opposing views regarding the worth and informational value of credit ratings have been put forward by Kräussl: ${ }^{18}$

The first view:

- That credit agencies only have access to publicly available information and that these agencies lag behind financial markets in processing such information. Further, Kräussl adds that credit rating changes should not affect market prices if financial markets are efficient in semi-strong form.

The opposing view not only argues that credit rating agencies are ,specialists in obtaining and

17 Basel Committee on Banking Supervision Working Papers, No 3 August 2000, Credit Ratings and Complementary Sources of Credit Quality Information at page $7 \mathrm{http}: / /$ www.bis.org/publ/bcbs_wp3.pdf

18 R Kräussl, „Do Credit Rating Agencies Add to the Dynamics of Emerging Market Crsies?“ CFS Working Paper No 2003/18 August 2003 at page 9 http:/www.frbatlanta.org/news/conferen/fsc04/kraeussl.pdf 
processing information“, but that sovereign credit changes, as well as negative credit ratings announcements are likely to generate more signficant impacts in emerging markets - owing to the level of severity of problems attributed to asymmetric information and transparency.

Why Credit Ratings Serve a Greater Role in Emerging Economies than Industrial Nations

It has been argued in many studies, that bank capital ratios and several other financial indicators do not serve as effectively in emerging market economies as is the case with industrial nations. According to Rojas-Suarez (2002), the capital-to-asset ratio, has under-performed as an indicator of banking crisis related problems in Latin America and Asia. ${ }^{19}$ Two reasons which have been put forward as explanations for this are: ${ }^{20}$

- Severe deficiencies in the accounting and regulatory framework in these jurisdictions;

- Lack of liquid markets for bank shares, subordinated debt and other bank liabilities and assets which are required to confirm and justify the actual worth of a bank - rather than merely its accounting value.

To which it will also be added that audits, which serve as vital signalling mechanisms in capital markets, have limited roles in many emerging economies than is the case with industrial nations.

However, it needs to be re- called that amongst several lessons drawn from the recent Financial Crisis, one of the most prominent is namely, the fact that, irregardless of whether a jurisdiction is an industrial nation or emerging economy, capital adequacy measures, on their own, no longer suffice as reliable measures or indicators of a bank's strength or ability to be resilient - particularly in times of crises. This, amongst other concerns - relevant to both industrial and emerging nations constitutes one of the principal reasons for the introduction of Basel III, and more specifically - the two liquidity standards, the Liquidity Coverage Ratio (LCR) and the Net Stable Funding Ration (NSFR), as well as the Basel III leverage ratios.

19 L Rojas-Suarez, „Rating Banks in Emerging Markets: What Credit Agencies Should Learn From Financial Indicators (2002) http://papers.ssrn.com/sol3/papers.cfm?abstract_id=300891

20 Ibid, see abstract 
IV

\section{The Need for Auditors and External Audits in An Increasingly Risk Based Regulatory Environment}

Risks have become not only increasingly significant in the modern regulatory environment, but also serve as vital regulatory tools. Auditors and audits, furthermore, serve as fundamental and crucial tools of quantifying risks. As highlighted several times, in the literature relating to risk, ,in order for risks to be quantifiable or governable, they must be auditable“. Coupled with the inherent uncertain nature of risks is also the quantifiable, as well as unquantifiable aspect and characteristic of risk. In this regard, it is important to distinguish between risk and uncertainty. Whilst risk is traditionally associated with probability calculations - which suggests that an event can be predicted and controlled, ,uncertainty is not capable of measurement and deals with possibilities incapable of calculation which are based on guesswork and judgement" ${ }^{21}$

In assessing whether the current regulatory framework appropriately and adequately balances the objectives, as set out in paragraph 29 of the Discussion Paper, „The Regulatory Framework: Balancing Risk Sensitivity, Simplicity and Comparability, “22 consideration is to be had to trade-offs required to find the right balance: Trade offs between costs in improving framework in a bid to improve complexity, risk sensitivity - at the possible expense of simplicity and comparability.

Is the desire to achieve comparability, as well as simplicity, greater than the need to attain accurate, reliable and more relevant results through investment in more complex techniques? Such techniques involving not only initially high outlays but also costs (as well as risks) involved in managing such techniques?

21 See J Gray and J Hamilton, Implementing Financial Regulation : Theory and Practice (2006) at page 20

22 July 2013 


\section{Conclusion}

In view of the inconsistencies and unreliability associated with relying solely on capital adequacy ratios, measures introduced by the Basel Committee, which are designed to reduce reliance on a single capital adequacy ratio as the primary means of ensuring the soundness of banks, are therefore welcomed. As indicated in the discussion paper, „The Regulatory Framework: Balancing Risk Sensitivity, Simplicity and Comparability“", such measures introduced by the Basel Committee, include: ${ }^{23}$

- The introduction of a leverage ratio

- An additional capital surcharge for global systemically important banks (G-SIBs)

- A proposed framework for measuring and controlling large exposures

- Minimum liquidity and funding standards

In support of the comments highlighted by the Committee in its discussion paper, ${ }^{24}$,risk is indeed multi-faceted and far from straight forward to measure“ - and whilst a risk sensitive regulatory framework, definitely offers a number of benefits, the complexity resulting therefrom bears with it, „potentially adverse consequences.“

The risk based capital regime should definitely remain at the core and focus of the regulatory framework for banks - supported by liquidity and funding metrics, as well as other measures such as the leverage ratio.

Furthermore, core principles ${ }^{25}$ relating to requirements for coordination and cooperation between

23 Basel Committee on Banking Supervision, 'The Regulatory Framework: Balancing Risk Sensitivity, Simplicity and Comparability' July 2013 at page $1 \mathrm{http} / / /$ www.bis.org/publ/bcbs258.pdf

24 See ibid

25 „The Basel Committee on Banking Supervision's Core Principles for Effective Banking Supervision (September 2012, Core Principles) provide a framework of minimum standards for sound supervisory practices and are considered universally applicable. Core Principle 27 focuses on prudential regulations and requirements for banks in relation to financial reporting and external audits.“ Paragraph 8, Basel Committee on Banking Supervision, Consultative Document, External Audits of Banks, March 2013 , page 2. Also see Basel Committee for Banking Supervision, „External Audit Quality and Banking Supervision“, December 2008 http://www.bis.org/publ/bcbs146.htm; and „The Relationship Between Banking Supervisors and Banks' External Auditors", January 2002 http://www.bis.org/publ/bcbs87.htm 
auditors and supervisors should constitute greater binding effects in all jurisdictions and for purposes of sovereign credit ratings determination. These principles should also be corroborated by provisions, rules and regulations which stipulate and require closer working relationships between national supervisors, external auditors and credit rating agencies.

Auditors' significance in the supervisory process in identifying areas of potential risks have also been acknowledged in various sections of the literature. ${ }^{26}$ If audits are performed as effectively, in the manner in which they are expected to be undertaken, then information provided by such audits should be credible and reliable. Whilst the informational issue with credit agencies appears to be the timely processing and transmission of information - a feature which depends on effective exchange, coordination and communication between those agencies and authorities involved, with audits, the crucial issue appears to be the level of credibility of information, which if effectively implemented, could be provided.

Audits therefore, do not only serve as risk regulatory tools, capable of quantifying and regulating risks, but also a means of verifying financial information within financial statements and addressing information asymmetries. In this sense, they fufil a vital position and dual role in addressing the rationales for financial regulation.

26 See M Ojo, „Audits, Audit Quality and Signalling Mechanisms: Concentrated Ownership Structures“ http://papers.ssrn.com/sol3/papers.cfm?abstract id=2372511 and Basel Committee for Banking Supervision, paragraph 6 page 31, Core Principles for Effective Banking Supervision September 2012 http://www.bis.org/publ/bcbs230.pdf 


\section{REFERENCES}

Basel Committee on Banking Supervision Working Papers, No 3 August 2000, Credit Ratings and Complementary Sources of Credit Quality Information

Basel Committee on Banking Supervision, 'The Internal Ratings Based Approach' Supporting Document to the New Basel Capital Accord' 2001 http://www.bis.org/publ/bcbsca05.pdf

Basel Committee on Banking Supervision, Consultative Document, Standard Approach to Credit Risk, Supporting Document to the New Basel Accord January 2001 http;//www.bis.org/publ/bcbsca04.pdf

Basel Committee on Banking Supervision, „The Relationship Between Banking Supervisors and Banks' External Auditors“, January 2002 http://www.bis.org/publ/bcbs87.htm

Basel Committee for Banking Supervision, „External Audit Quality and Banking Supervision“, December 2008 http://www.bis.org/publ/bcbs146.htm

Basel Committee on Banking Supervision, the Joint Forum, Stocktaking on the Use of Credit Ratings June 2009

http://www.bis.org/press/p090615.htm

Basel Committee for Banking Supervision, Core Principles for Effective Banking Supervision September 2012 http://www.bis.org/publ/bcbs230.pdf

Basel Committee on Banking Supervision, 'The Regulatory Framework: Balancing Risk Sensitivity, Simplicity and Comparability' July 2013 http://www.bis.org/publ/bcbs258.pdf 
Basel Committee on Banking Supervision, Consultative Document, External Audits of Banks, March 2013

Basel Committee for Banking Supervision, Standardised Approach for Measuring Counter Party Credit Risk March 2014 http://www.bis.org/publ/bcbs279.htm

Basel Committee for Banking Supervision, Capital Requirements for Bank Exposures to Central Counterparties, April 2014

Gray J and Hamilton, J Implementing Financial Regulation : Theory and Practice (2006)

IMF Working Paper, Sovereign Credit Ratings and Spreads in Emerging Markets: Does Investment Grade Matter? March 2011 WP/11/44

Kräussl, R „Do Credit Rating Agencies Add to the Dynamics of Emerging Market Crsies?" CFS $\begin{array}{lllll}\text { Working } & \text { Paper } & \text { No } & 2003 / 18 & \text { August }\end{array}$ http://www.frbatlanta.org/news/conferen/fsc04/kraeussl.pdf

Ojo, M „Audits, Audit Quality and Signalling Mechanisms: Concentrated Ownership Structures“ http://papers.ssrn.com/sol3/papers.cfm?abstract id $=2372511$

Rojas-Suarez, L „Rating Banks in Emerging Markets: What Credit Agencies Should Learn From Financial Indicators (2002) http://papers.ssrn.com/sol3/papers.cfm?abstract_id=300891 